\title{
(2) OPEN ACCESS \\ Bilateral liquefactive corneal necrosis: a rare and devastating complication of vitamin A deficiency in the adult
}

\author{
Suman Lata 주, Rahul Kumar Bafna 다, Mohamed Ibrahime Asif, Anusha Sachan
}

Ophthalmology, Dr. Rajendra Prasad Center for Ophthalmic Sciences, All India Institute of Medical Sciences (AllMS), New Delhi, India

\section{Correspondence to}

Dr Suman Lata;

suman.dhanda300@gmail.com

Accepted 5 February 2021

Check for updates

(C) BMJ Publishing Group Limited 2021. Re-use permitted under CC BY-NC. No commercial re-use. See rights and permissions. Published by BMJ.

To cite: Lata S, Bafna RK, Asif MI, et al. BMJ Case Rep 2021;14:e237343. doi:10.1136/bcr-2020 237343

\section{SUMMARY}

A 34year-old man presented with diminution of vision, pain and whitish opacity in both eyes (right eye followed by left eye) since 1 week. He is a known case of chronic alcoholic abuse. He had multiple episodes of haemoptysis in the past. On general physical examination, he was severely malnourished with multiple oral ulcers. Visual acuity at presentation was light perception in both eyes with projection of rays accurate in all quadrants. Slitlamp biomicroscopy revealed bilateral total corneal melt with diffuse conjunctival congestion. Corneal scrapings and blood investigations were done and he was started on empirical topical and systemic therapy followed by surgical intervention, with large corneal grafts in both the eyes (right eye followed by left eye) with 1 day interval. The visual gain in both the eyes were 20/400 at first postoperative day. The right eye developed severe fibrinous reaction on the second postoperative day which resolved with topical antibiotics, topical steroids and systemic steroids. The patient was followed up via telemedicine (due to COVID-19 outbreak) and he is able to carry out his daily routine work independently.

\section{BACKGROUND}

Vitamin A deficiency is a leading cause of preventable blindness especially in developing and underdeveloped nations. ${ }^{1}$ It is predominantly seen in childhood but can affect adults secondary to severe malnutrition/malabsorption/liver disease/chronic alcoholism. $^{2-5}$ It can lead to a spectrum of ocular changes from mild conjunctival xerosis to severe corneal ulcers and perforations. The purpose of this case report is to highlight the importance of diagnosis and early intervention of this potentially devastating complication of vitamin A deficiency in an adult due to chronic alcohol abuse and malnutrition.

\section{CASE PRESENTATION}

A 34-year-old man presented to us with a history of painful, progressive diminution of vision in both the eyes for the past 1 week. He had associated redness and whitish opacity in both the eyes, the right eye followed by the left eye (figures 1 and 2, respectively) for which he had used topical antibiotics since 3 days. He is a known alcoholic for the past 10 years. The patient had multiple episodes of haemoptysis in the past. On general physical examination, the patient was severely malnourished and had difficulty in swallowing due to multiple oral ulcers. Visual acuity in both eyes were perception of light present with projection of rays accurate in all quadrants. The eyelids and adnexal structures appeared normal. There was diffuse conjunctival congestion and mild chemosis present in both eyes. Cornea of both eyes revealed total corneal melt with fluorescein uptake on staining (figures 3 and 4), with peripheral thinning and adjacent limbitis. There was no vascularisation as one would expect in an infective pathology. Rest of the anterior chamber details and fundus could not be visualised. Ultrasonography of both the eyes for posterior segment evaluation were unremarkable.

\section{INVESTIGATIONS}

- Corneal scrapings from both the eyes were performed. Gram's stain and $\mathrm{KOH}$ stain did not reveal any microbial organisms. Bacterial and fungal cultures were sent. Tear PCR was performed for herpes simplex virus.

- A panel of blood investigations were sent as the patient was severely malnourished and ocular examination revealed peripheral corneal thinning. Haemogram, erythrocyte sedimentation rate, $\mathrm{C}$ reactive protein, rheumatoid factor assay, antinuclear antibody assay, anticyclic citrullinated peptide assay, cytoplasmic antineutrophil cytoplasmic antibody (ANCA), perinuclear ANCA, serum calcium and ACE were performed. The patient underwent a peripheral blood smear examination to rule out haematological malignancy. Stool examination was performed to rule out any occult blood or parasites.

- Monteaux test and chest X-ray were done to rule out tuberculosis.

- The patient was evaluated for infectious aetiology: HIV-1, HIV-2, hepatitis B surface antigen, hepatitis $\mathrm{C}$ virus and venereal disease research laboratory test testing. All the above reports were inconclusive for any probable aetiology.

- The patient was referred to a gastroenterologist and was advised for further evaluation for vitamin deficiencies. On investigating, the patient was found to be deficient in all the essential vitamins including vitamins $\mathrm{A}$ and $\mathrm{B}_{12}$. The levels of vitamin A was significantly decreased to $0.2 \mu \mathrm{mol} / \mathrm{L}$ (normal range $0.9-2.5$ $\mu \mathrm{mol} / \mathrm{L}$ ). The retinol binding protein level was also reduced to $11 \mathrm{mg} / \mathrm{L}$ (normal range 30-90 $\mathrm{mg} / \mathrm{L})$. 


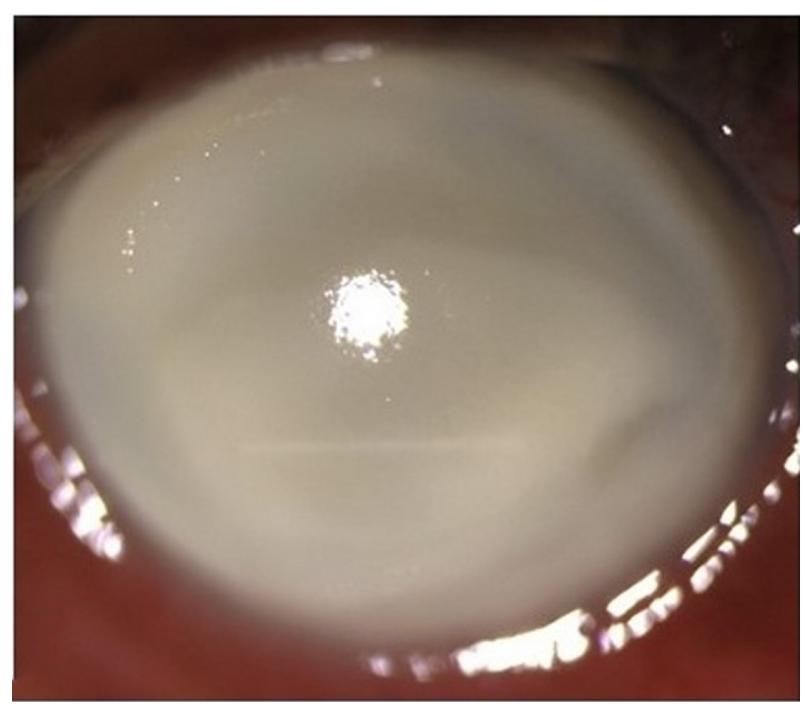

Figure 1 Clinical picture right eye showing liquifactive corneal necrosis.

\section{DIFFERENTIAL DIAGNOSIS}

The possible differential diagnosis in our case was bilateral infective keratitis, peripheral ulcerative keratitis (PUK), protein energy malnutrition along with multiple vitamin deficiencies leading to bilateral corneal melt. The other very rare differential diagnosis was acute metastatic corneal abscess. The first differential diagnosis was bilateral infective keratitis for which corneal scrapings were taken and sent for bacterial and fungal culture; Gram and $\mathrm{KOH}$ staining were performed which came out to be negative for any infective pathology. The next differential diagnosis was autoimmune diseases leading to corneal melt. The patient was thoroughly worked up for systemic autoimmune disease with the help of haematological and radiological battery of investigations. All reports came out to be inconclusive and ruled out any autoimmune involvement. The patient underwent investigations to rule out protein energy malnutrition and reports supported essential vitamin deficiencies including vitamins $A$ and $B_{12}$. Hence, the diagnosis of bilateral liquifactive necrosis due to vitamin A deficiency was made and the patient

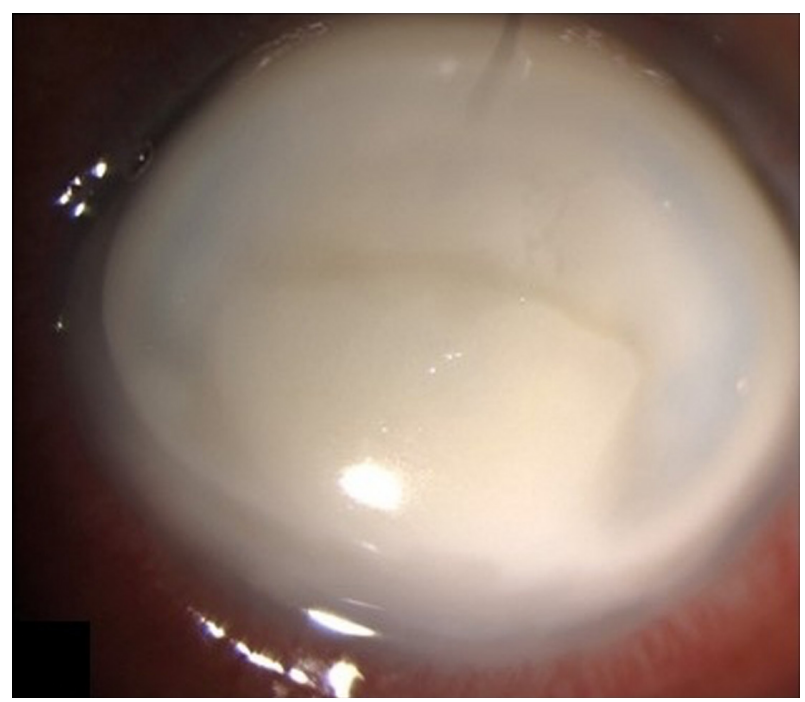

Figure 2 Clinical picture of left eye showing liquifactive corneal necrosis.

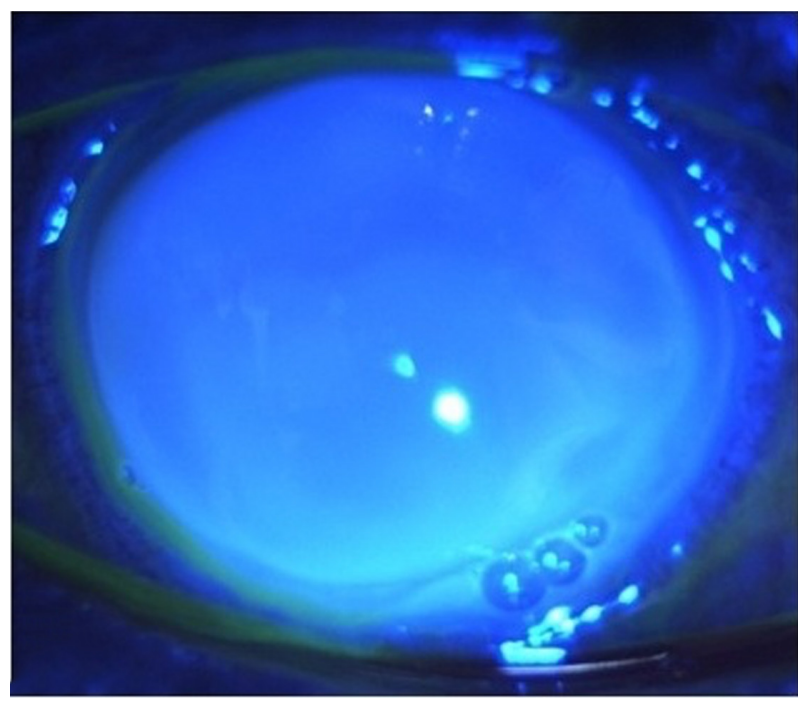

Figure 3 Fluorescein-stained picture of right eye, showing corneal melt taking up the fluorescein stain.

was treated with systemic vitamin A supplementation and diet, including essential vitamins and proteins.

\section{TREATMENT}

The patient was started on empirical topical therapy with fortified eye drops (concentrated cefazolin 5\%, concentrated tobramycin $1.3 \%$ instilled hourly), topical cycloplegics and oral antibiotics. The patient was treated with intravenous multivitamin (containing 10000 IU vitamin A, C, D, E and B complex) for 5 consecutive days. 200000 IU of vitamin A was administered orally once a week subsequently. The patient was also started on oral vitamin $\mathrm{C}$ and doxycycline. The patient underwent large size, corneal transplantation in both eyes, right followed by left (figures 5 and 6, respectively), on day 2 of intravenous medication. The host corneal buttons were sent for microbiological and histopathological examination (HPE). Cultures were sterile and HPE revealed necrosis of corneal tissue.

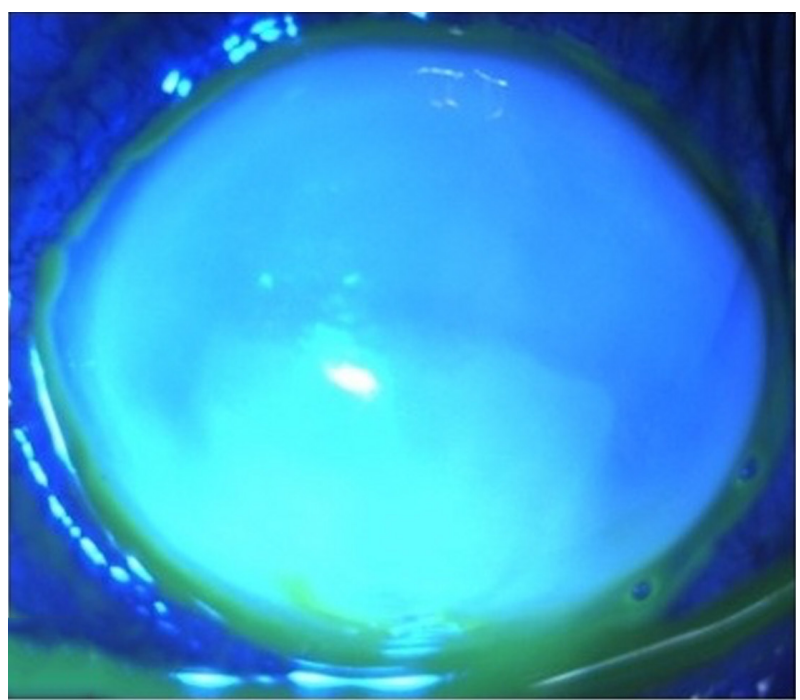

Figure 4 Fluorescein-stained picture of left eye, showing corneal melt taking up the fluorescein stain. 


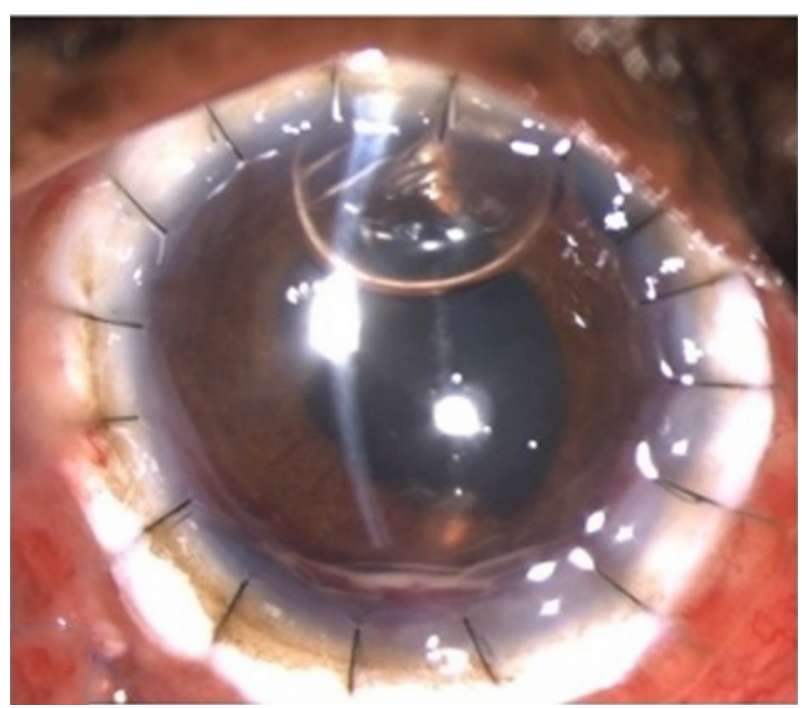

Figure 5 Postoperative day 2 picture of the right eye showing severe inflammatory reaction (treated with topical and oral steroids).

\section{OUTCOME AND FOLLOW-UP}

Postoperative visual acuity on day 1 was 20/400 in both the eyes. The right eye developed an inflammatory reaction on day 2 of surgery, which subsided with topical steroids and oral steroids. The topical antibiotics, steroids, lubricants and antiglaucoma medication, as well as oral vitamin $\mathrm{C}$ and doxycycline, were continued in the postoperative period. The patient could not follow-up due to COVID-19 pandemic, but was followed up via telemedicine. The patient is able to perform his routine work independently and does not have any problems.

\section{DISCUSSION}

We present a rare case of protein-energy malnutrition with vitamin A deficiency secondary to chronic alcoholism, leading to bilateral total corneal melt with peripheral thinning. Vitamin A deficiency is more prevalent in children, but in adults, it has been described in association with disorders such as cystic fibrosis, ${ }^{6}$ anorexia nervosa ${ }^{7}$ and chronic alcoholism. ${ }^{8}$ Vitamin A deficiency causes a spectrum of ocular diseases, from conjunctival xerosis

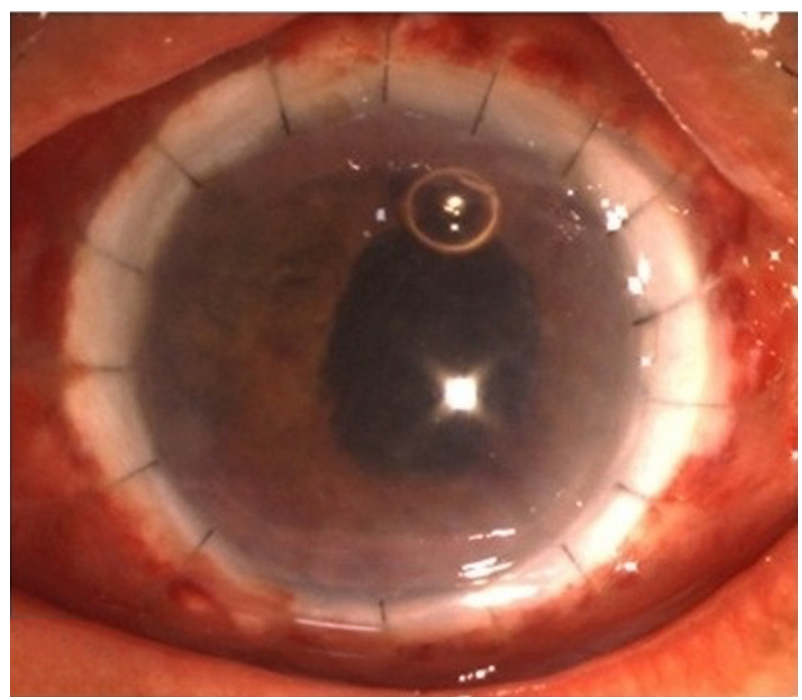

Figure 6 Postoperative day 2 picture of the left eye showing wellformed anterior chamber and mild inflammatory reaction. to corneal perforations known as xerophthalmia spectrum. ${ }^{9-11}$ Conjunctival xerosis with keratinising squamous metaplasia, loss of goblet cells and heaped up accumulations of keratin (Bitot spots) are characteristic, and corneal pathology can range from mild epitheliopathy to fulminant keratomalacia, resulting in blindness. ${ }^{9-11}$ Rarely, they can present as PUK, as in our case. ${ }^{12}$

Vitamin A-derived retinoids are considered responsible for regulation of production of mucins by the stratified epithelium of the conjunctiva and cornea as well as the conjunctival goblet cells. ${ }^{13}$ Mucins maintain the epithelium-tear film interface due to their hydrophilic glycoproteins that keeps the ocular surface moist. Retinoid signalling negatively regulates keratinising squamous metaplasia of the epithelium. ${ }^{14}$ Vitamin A downregulation of collagenase and other protease secretion maintains the corneal stroma; unchecked level of these can lead to stromal thinning. ${ }^{15}$ Vitamin A deficiency can result in depletion of the retinaldehyde chromophore from retinal photoreceptors, subsequently resulting in photoreceptor degeneration and fundus depigmentation from the focal retinal pigment epithelial loss and presents as nyctalopia.

This case highlights the need for extensive evaluation and early intervention in patients with blinding complication of vitamin $\mathrm{A}$ deficiency. Vitamin A deficiency is easily overlooked in adults. However, a high index of suspicion has to be kept, especially in chronic alcoholics and in severe malnutrition, as in our case. Our patient also had oral ulcers which raised the suspicion of nutritional deficiency. The reason for vitamin A deficiency in our patient must be due to decreased intake which was exacerbated by chronic alcohol abuse. Vitamin A substitution along with management of protein-energy malnutrition with alcohol abstinence helped in improving the systemic status of our patient.

Therefore, in a case of bilateral sterile corneal melt in a malnourished patient or with any of the above-mentioned risk factors, vitamin A deficiency should be suspected. The goal of management should be systemic replenishment of vitamin A stores along with appropriate ocular management. It is important to note that if vitamin A deficiency is associated with a proteinenergy malnutrition syndrome, both must be corrected at the same time to avoid recurrence of the symptoms within weeks after therapy.

\section{Learning points}

Vitamin A deficiency can present in any age group. In adults, it could have varied presentation with bilateral sterile corneal melt, with peripheral thinning being a rare and severe manifestation.

- Cases of bilateral ocular involvement in a severely malnourished or chronic alcoholic patient should raise the suspicion of vitamin A deficiency. Early surgical intervention along with systemic management in severe cases could have better visual outcomes for the patient.

- Urgent referral for systemic evaluation and early vitamin A supplementation could be useful in these patients.

\section{Twitter Anusha Sachan @Anusha Sachan}

Contributors SL, the corresponding author, worked up the case and operated on both eyes of the patient. RKB helped with detailed investigations. MIA recorded and collected clinical pictures of the patient, both pre-surgical and post-surgical intervention.

Funding The authors have not declared a specific grant for this research from any funding agency in the public, commercial or not-for-profit sectors.

Competing interests None declared. 
Patient consent for publication Consent obtained directly from patient(s).

Provenance and peer review Not commissioned; externally peer-reviewed.

Open access This is an open access article distributed in accordance with the Creative Commons Attribution Non Commercial (CC BY-NC 4.0) license, which permits others to distribute, remix, adapt, build upon this work non-commercially, and license their derivative works on different terms, provided the original work is properly cited and the use is non-commercial. See: http://creativecommons.org/ licenses/by-nc/4.0/.

ORCID iDs

Suman Lata http://orcid.org/0000-0002-2218-3130

Rahul Kumar Bafna http://orcid.org/0000-0002-6795-0508

Anusha Sachan http://orcid.org/0000-0001-9737-6706

\section{REFERENCES}

1 Thylefors B, Négrel AD, Pararajasegaram R, et al. Global data on blindness. Bull World Health Organ 1995:73:115-21.

2 Bishara S, Merin S, Cooper M, et al. Combined vitamin A and E therapy prevents retinal electrophysiological deterioration in abetalipoproteinaemia. $\mathrm{Br} J$ Ophthalmol 1982;66:767-70.

3 Russell RM, Morrison SA, Smith FR, et al. Vitamin-A reversal of abnormal dark adaptation in cirrhosis. study of effects on the plasma retinol transport system. Ann Intern Med 1978;88:622-6.

4 Rogers EL, Douglass W, Russell RM, et al. Deficiency of fat soluble vitamins after jejunoileal bypass surgery for morbid obesity. Am J Clin Nutr 1980;33:1208-14.
5 Eckert MJ, Perry JT, Sohn VY, et al. Incidence of low vitamin A levels and ocular symptoms after Roux-en-Y gastric bypass. Surg Obes Relat Dis 2010;6:653-7.

6 Brooks HL, Driebe WT, Schemmer GG. Xerophthalmia and cystic fibrosis. Arch Ophthalmol 1990;108:354-7.

7 Berthout A, Sellam M, Denimal F, et al. [The eye and anorexia nervosa. A case report]. J Fr Ophtalmol 2007:30:e15.

8 Benítez Cruz S, Gómez Candela C, Ruiz Martín M, et al. [Bilateral corneal ulceration as a result of caloric-protein malnutrition and vitamin A deficit in a patient with chronic alcoholism, chronic pancreatitis and cholecystostomy]. Nutr Hosp 2005:20:308-10.

9 McLaughlin S, Welch J, MacDonald E, et al. Xerophthalmia--a potential epidemic on our doorstep? Eye 2014:28:621-3.

10 McLaren DS, Oomen HA, Escapini H. Ocular manifestations of vitamin-A deficiency in man. Bull World Health Organ 1966:34:357-61.

11 Smith J, Steinemann TL. Vitamin A deficiency and the eye. Int Ophthalmol Clin 2000;40:83-91.

12 Lange AP, Moloney G, Sheldon CA, et al. Bilateral corneal ulceration caused by vitamin A deficiency in eosinophilic gastroenteropathy. Case Rep Ophthalmol 2011:2:302-6.

13 Hori Y, Spurr-Michaud SJ, Russo CL, et al. Effect of retinoic acid on gene expression in human conjunctival epithelium: secretory phospholipase A2 mediates retinoic acid induction of MUC16. Invest Ophthalmol Vis Sci 2005;46:4050-61.

14 Samarawickrama C, Chew S, Watson S. Retinoic acid and the ocular surface. Surv Ophthalmol 2015;60:183-95.

15 Twining SS, Hatchell DL, Hyndiuk RA, et al. Acid proteases and histologic correlations in experimental ulceration in vitamin A deficient rabbit corneas. Invest Ophthalmo/ Vis Sci 1985;26:31-44.

Copyright 2021 BMJ Publishing Group. All rights reserved. For permission to reuse any of this content visit https://www.bmj.com/company/products-services/rights-and-licensing/permissions/

BMJ Case Report Fellows may re-use this article for personal use and teaching without any further permission.

Become a Fellow of BMJ Case Reports today and you can:

- Submit as many cases as you like

- Enjoy fast sympathetic peer review and rapid publication of accepted articles

- Access all the published articles

Re-use any of the published material for personal use and teaching without further permission

\section{Customer Service}

If you have any further queries about your subscription, please contact our customer services team on +44 (0) 2071111105 or via email at support@bmj.com.

Visit casereports.bmj.com for more articles like this and to become a Fellow 